\title{
AC 2009-1879: THE BIG PICTURE: USING THE UNFORESEEN TO TEACH CRITICAL THINKING
}

\section{Christy Moore, University of Texas, Austin}

CHRISTY MOORE is a Senior Lecturer in the Department of Mechanical Engineering at the University of Texas at Austin where she teaches engineering communication courses and a signature course on "Society, Technology, and the Environment." Her pedagological and research interests include service-learning projects, engineering ethics and professional responsibility, research ethics, and strategies for advancing students' analytical and rhetorical skills. She is co-PI on an NSF project, The Foundations of Research Ethics for Engineers (FREE) and collaborated on the development of the PRiME (Professional Responisibility Modules for Engineers) Learning Modules, a suite of web-based modules designed to introduce undergraduates to engineering ethics.

\section{D'Arcy Randall, University of Texas, Austin}

D'Arcy Randall is a Lecturer in Chemical Engineering at the University of Texas at Austin, where she teaches undergraduate and graduate classes in Engineering Communications. Through UT's Study Abroad Program, she initiated a Summer in Spain class for UT's undergraduate engineers at the Universidad de Cantabria. She also created and maintains The Chemical Engineering Communications Website (http://www.engr.utexas.edu/che/techwriting), an online textbook for communication and laboratory classes. Her research interests include methods of teaching engineering ethics, argumentation, and graduate-level writing.

\section{Hillary Hart, University of Texas, Austin}

Hillary Hart is Distinguished Sr. Lecturer in the Department of Civil, Architectural and Environmental Engineering, where she created and directs the program in engineering communication. She has published one book (two editions) and over 20 technical articles on environmental and risk communication, engineering ethics, and technical communication. A Fellow of the Society for Technical Communication, Hillary also works with companies, such as BP-Amoco, and public agencies to develop strategies for socially just, interactive communication among engineers, regulators, industry, and the public on environmental issues. She has recently begun exploring with her undergraduate classes the connection between ethical argumentation and visual representations. 


\section{The Big Picture: Using The Unforeseen to Teach Critical Thinking}

I think the current trend in documentary-is all about polarizing and-advancing one political agenda while denigrating the other half of the population. . . I wanted to make a story that reflected the true complexities of the issue and got at the subject in a way that might shed new light on an issue that we all know about...

Director Laura Dunn describing The Unforeseen. ${ }^{1}$

Abstract

In our undergraduate Engineering Communication courses we help students develop their analytical skills through teaching argumentation. For several years we have used documentary film as a tool to engage students in a meaningful and stimulating discussion of rhetorical strategies and the principles of argumentation. Although documentaries, such as $A n$ Inconvenient Truth and Who Killed the Electric Car, are useful for this purpose in many ways, students are resistant to perceived bias and editorializing in those films and others like them. In 2008, we began using The Unforeseen, a documentary that employs a different strategy, and according to the filmmaker, rejects "the current trend in documentary" to polarize people by denigrating one position and elevating another. In this paper we describe how we have used The Unforeseen in our Engineering Communication courses to introduce basic concepts of argumentation, such as ethos, pathos, and logos; present the results of students' efforts to analyze the film's rhetorical strategies; and analyze the pedagogical impact of using a film that presents many facets and perspectives of a complex issue.

\section{Introduction}

In "The Future of Engineering Education," Eric Soulsby suggests that our job as engineering educators is to train "engineering problem-solvers" not only to think critically about their technical challenges but also "to apply [their] knowledge to broader societal needs." ${ }^{2}$ His coauthors echo his sentiments in their repeated emphasis on the importance of analysis in engineering education. As communication instructors we can think of no better way to teach analysis and critical thinking skills than by teaching rhetoric and argumentation. John Ramage and John Bean note in their watershed textbook that the purpose of argument is not simply to sway the audience, "but also to help the writer clarify his or her own thinking on an issue." Argumentation they tell us "[i]s not an end in itself: rather, it is a means to achieving good decisions." 3 If teaching argumentation can help students to clarify their thoughts, think more deeply about the world, and make better decisions, chances are they will be better equipped to solve complex engineering problems for the world's peoples.

In our undergraduate Engineering Communication courses we have discovered that one way to engage students in a meaningful discussion of argument is by analyzing the rhetoric in documentary films. Documentaries such as An Inconvenient Truth (2007) and Who Killed the Electric Car? (2006) have a relevance to engineering and technology that make them suitable for discussion in engineering classes. In addition, these films present arguments that allow us to 
introduce the concept of persuasive appeals, the structure of arguments, and the categories of arguments.

One problem, however, that communications professors encounter in teaching basic

argumentation skills to engineering undergraduates is that the slightest perception of "bias" in an argument typically provokes resistance. Instead of being stimulated by the challenge, students tend to dismiss the argument altogether. We have tried, over the years, to introduce visual and verbal rhetoric through the use of films such as The Corporation (2003) or Enron: The Smartest Guys in the Room (2005), yet class discussions stall or veer into one-sided polemics. Even An Inconvenient Truth has elicited student criticism for being too "biased." Students simply point to Al Gore's known political positions to explain his bias - a response that requires little analysis. In fact, those who did not support Gore dismiss his film quickly without thinking much further than his identity.

In 2008, we began using The Unforeseen, a 2006 documentary that employs a different strategy. When it premiered at the Sundance Film Festival, film critic Gavin Smith called The Unforeseen the "best film of the festival, hands down" and described the film's "account of the opposition of local residents to a series of proposed suburban subdivision developments in Austin, Texas" as "truly engrossing". 4 Other reviewers have noted that the film approaches its controversial topic - the conflict between environmentalism and urban development -- through thoughtful analysis rather than polemic claims. Robert Koehler of Variety for instance calls it "a visual, scientific and philosophic rumination of humanity's place on the planet and the limits to growth." 5 For our purposes as teachers, we find that the balance between arguments and counter arguments presented in the film encourages civil debate and the sort of clarifying examination of ideas that Ramage and Bean advocate. In this paper we describe and analyze our use of The Unforeseen in our Engineering Communication courses to teach argumentation and help our students learn to analyze complex issues.

Summary of the Film

Winner of the 2008 Independent Spirit Award "Truer than Fiction" Prize, The Unforeseen explores a decades-old debate between environmentalists and developers in Central Texas. According to the promotional materials for the film it is a "meditation on the American dream on the destruction of the natural world as it falls victim to the cannibalizing forces of unchecked development. It is an intricate tale of personal hopes, victories, and failures, and of debates over land, water and the public good". 6 The debate in the film is focused on a natural, spring-fed swimming pool in the center of Austin, Texas: Barton Springs. Loved by generations of Austinites, Barton Springs has been in the past and continues to be threatened by the impact of development. The film chronicles two main narrative lines. The first is the growth of a grassroots environmental advocacy movement to protect Barton Springs. The second chronicles the career of a developer, Gary Bradley, whose success in transforming "4,000 acres of pristine Hill Country into one of the state's largest and fastest selling subdivisions" 6 made him the target of that environmental movement to protect Barton Springs. 
Austin filmmaker Laura Dunn's alliance is clearly on the side of the environmentalists. At the same time, though, she evenhandedly explores other sides of the issues: namely, property rights and the American dream of home ownership. Her cast of characters, in addition to Gary Bradley and the many local activists, include Robert Redford who speaks for the environmental movement; homeowners in a new subdivisions, who have discovered there isn't enough water to keep their new lawn alive; a farmer, Curtis Peterson, who remembers the way things were; Willie Nelson, who compares Austin to Maui; William Greider, a reporter for Rolling Stone, who believes that developers in some sense embody the can-do American spirit; and an oncologist, Judah Folkman, who explains the difference between the growth of cancer cells in the body and healthy growth. The film's conclusion seems to be that urban growth in itself is not bad, but unhealthy growth, such as the overdevelopment that threatens the environmental health of the Texas hill country, is like cancer. The conflict portrayed in the film is a reflection of similar conflicts arising throughout the country as communities struggle to balance the American dream of home ownership with the pitfalls of suburban sprawl.

The film is rich with opportunities to encourage students to think critically about the impacts of development and to analyze what Soulsby calls "broader societal needs." We do this in the classroom by looking at the rhetorical structure of the film, using it as a tool to introduce our students to the concept of argumentation, and promoting a meta-critical self-discovery whereby students can examine their own biases, as well as the film's. The film itself models a rhetorical structure in which point of view does not have to become "bias." Dunn demonstrates that one can have a position on a set of issues without being biased or unbalanced in the argument.

Pathos, Ethos, Logos

The first step in reaching our pedagogical goal to develop students' critical thinking is to go back to Aristotle. Aristotle's Rhetoric introduces the concepts of pathos, ethos, and logos as three essential "modes of persuasion" in verbal argumentation. Pathos refers to the mode by which the writer/speaker appeals to the emotions of the audience; ethos to the writer's own credibility; logos to the strength of the argument itself. Today, these modes are usually taught as the three corners of a "rhetorical triangle"(see Fig. 1), and visual representations are included. For instance, in the introductory Engineering Communication lecture, the instructor typically presents a rhetorical triangle and illustrates the three modes through examples in popular media.

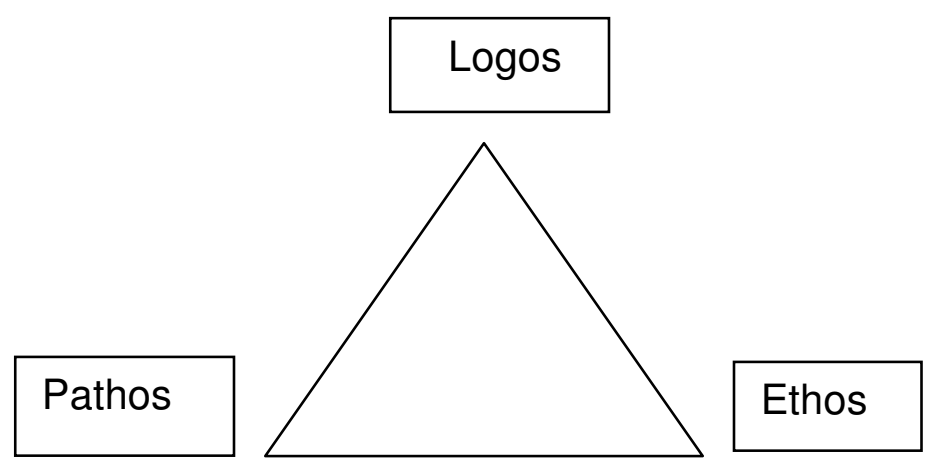

Figure 1: A Rhetorical Triangle 
Engineering students are usually quick to identify the modes of persuasion in automobile advertisements, which appeal to pathos through romantic or adventurous settings, ethos through the reputation of the manufacturer, and-sometimes-logos through the specifications. We explain that the modes often overlap. For instance, the logo of a highly prestigious automobile manufacturer appeals simultaneously to both ethos and pathos: quality and reliability blend with glamour and prestige. Follow-up discussion examines the modes of persuasion in short written arguments, such as those for or against various means of conserving energy or the environment. We find that students sift easily through pathos and ethos appeals, but most require more time, reading, and guidance for appeals to logos.

In the spring of 2008, after the introductory lectures, our students watched The Unforeseen and 119 of them answered homework questions that required them to identify and evaluate the various modes of persuasion used in the film. We then drew from their responses in class discussion. Not surprisingly, students readily identified the emotional and authoritative appeals in the film and recognized their relative importance in conveying the film's main points.

\section{Pathos}

Students not only located sites of pathos, but noted its dominant presence in the film. Approximately one quarter of the students (28 out of a total of 119) drew attention to the multiple scenes in which citizens voiced their concern for the Springs (see Fig. 2):

"The courthouse scene with many people from all walks of life coming together to voice a uniform opinion [is one example of pathos]. The emotional appeal is with everyday citizens coming together to fight a big corporation, which is a "David and Goliath" like task. Everyone can appeal to those standing up for what they believe in."
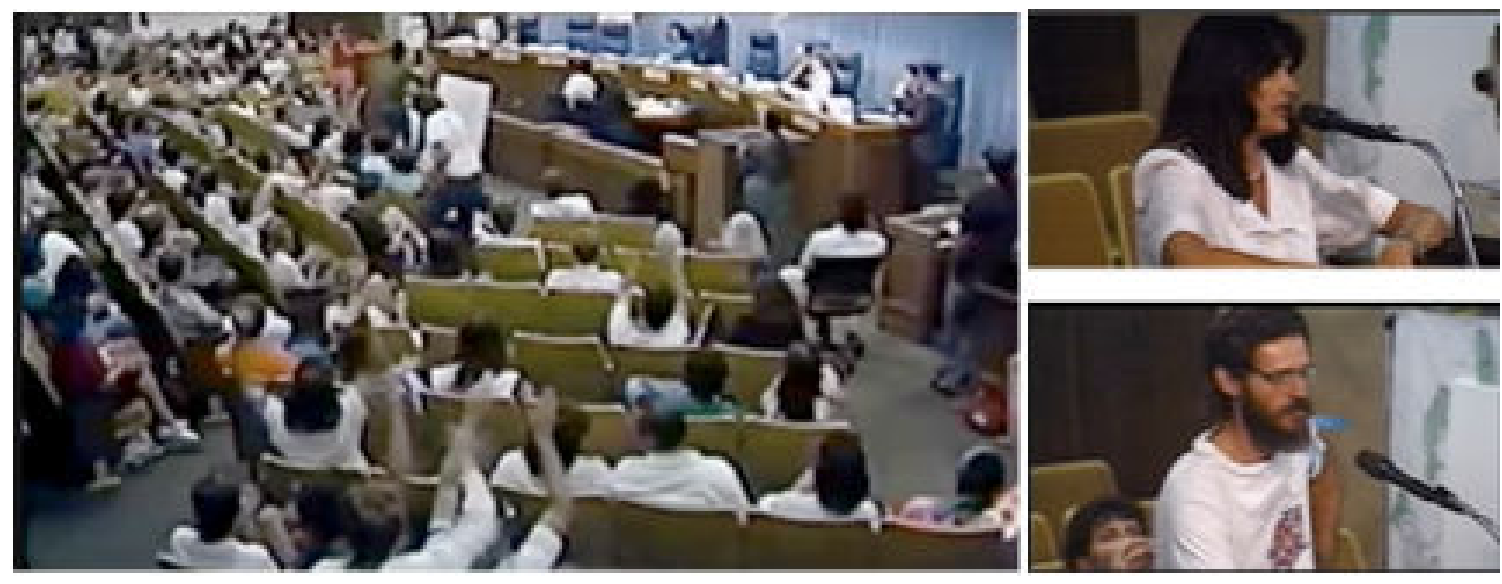

Figure 2. Citizens voicing their concerns at an all-night Austin City Council hearing, June 7, 1990.

A similar proportion of students noted pathos in the images of families and children in nature:

"She appealed to family closeness and environmentalism with scenes of families having fun in Barton Springs. This is very convincing because it reminds people of the importance of Barton Springs to the people in Austin." 
One student was impressed by

"...the sentimental value of nature to generations of people. It made a powerful statement about the connection we still have with nature and how it can unite people into a single cause."

Students generally drew attention to Dunn's use of pathos in her images of Austin before and after development. This full response by one student reflects the observations of many:

"Dunn appeals to emotion the most, almost always [to show] opposition to the growth [of development in Austin]. Many people talk about the spiritual nature of the springs and their emotional worth, and most of the imagery in the film is designed to invoke an emotional response opposing the growth. For instance, the film uses footage of a man painting miniature bombs while he talks about his role in lobbying for the bill which allowed development. Additionally, at one point the film zooms in on the footage of a cross being overcome by concrete, a powerful image which suggests the destructive nature of development."

Three individuals interviewed in the film - the developer Gary Bradley, the farmer Curtis Peterson, and (to a lesser degree) Robert Redford-were frequently listed as conveying pathos. Bradley's interviews weave through the film, from beginning to end. In one early scene, Bradley recalls his humble, rural beginnings in west Texas, and how, after his move to Austin, he could not help but notice the commercial potential of the region's abundant water supply. Through the middle of the film, he recalls a series of fights and lawsuits with environmentalists and the government. Finally, he recalls filing for bankruptcy, which occurred shortly before his mother's death. As he describes his shame in returning to west Texas, standing by his mother's grave surrounded by his "true peers," he weeps (see Fig. 3). Many students were moved by this scene of a "grown man crying." For one student, the scene "brought the documentary into [the realm of] more personal feelings instead of just being a movie". Another wrote that the scene "went against the filmmaker's point by showing [that Bradley] was not some emotionless monster, and that he is a human with cares and worries."

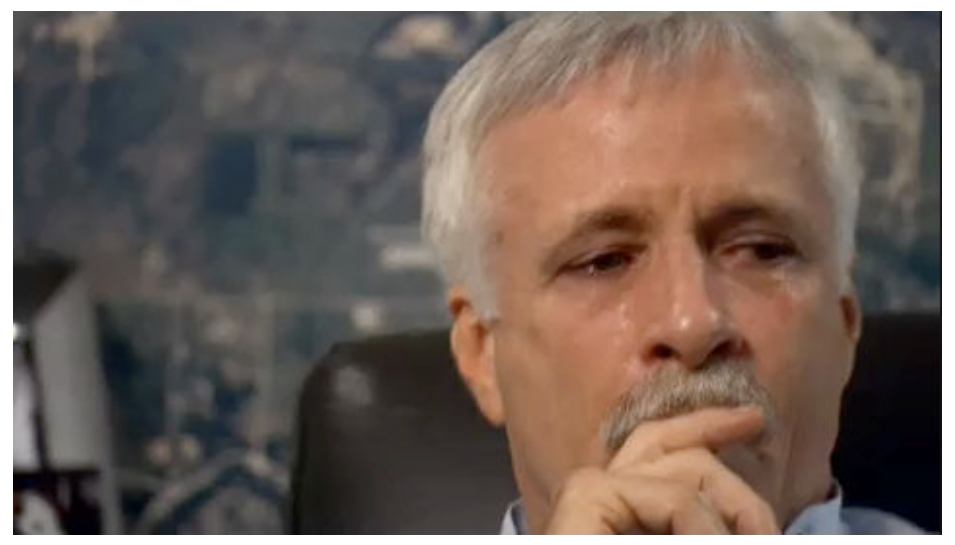

Figure 3. Gary Bradley reflects on the impact of his bankruptcy. 
Students were also stirred by scenes featuring Curtis Peterson (shown in Fig. 4.) whose livelihood as a farmer is threatened by new developments near his land:

"When the farmer was talking about [food and] water shortage, and he was standing holding wheat looking at the construction equipment mowing down the field next to him, it made me feel like there wasn't any hope for the farmer or for the common individual in the face of developers."

Writing about this scene, another student proposed, "One might even [draw] an analogy between the farmer's weathered face and the scars left by unhealthy developmental construction."

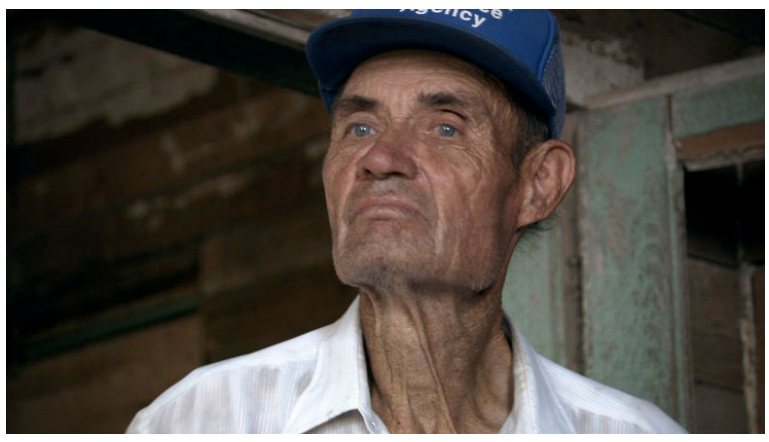

Figure 4. Curtis Peterson, a local farmer whose livelihood is threatened by development.

Robert Redford, a co-producer of the film, speaks in the film of how he learned to swim at Barton Springs, and of how that experience fostered his environmentalism. He states adamantly of Barton Springs that we should "leave it alone." He draws a comparison between how Los Angeles has been spoiled by unbridled growth, and how Austin could face a similar future. Students commented on the emotional appeal of Redford's "childhood memories" and "nostalgia," but several went further and pointed out how Dunn used Redford's interview to set up contrasts with those of real estate speculator Marshall Kuykendall, who focuses "only on money," and the aggressive lobbyist with his model bombs.

Overall, most students accurately identified Dunn's use of pathos. The appeal of Redford, however, was striking in that nearly equal numbers of students commented on his ethos, or authority, as on his pathos.

\section{Ethos}

Robert Redford stood out among all interviewees for his appeal to ethos. Most students who mentioned Redford found him credible; several found his comparison between Austin and Los Angeles persuasive. A few, however, recognized Redford's role but questioned his ethos, largely because they considered him an "actor" rather than an "expert." Another wrote that "though Robert Redford's involvement lends the film a more powerful voice and seems to lend it authority, his monologue was anecdotal rather than authoritative." 
Two other characters emerged with a complex ethos. One student found Gary Bradley to be a "credible businessman"; another found Bradley's credibility "very low" after his trial. A third was drawn to Bradley's "typical American story" while simultaneously noting that the film shows him as "just looking for a profit."

Other sources of questionable authority were politicians, including a former governor, the late Ann Richards. Students varied widely in their assessment of Richard's credibility. A Richards admirer pointed out that "she was a part of the decisions and she spoke authoritatively. One Richards critic, however, objected to her "partisan politics," and two others declared that her famous comment that George W. Bush was a "jerk" compromised her credibility.

Students were even less impressed by Jim Bob Moffett, CEO of Freeport-McMoRan, whose attempt to develop land over the Edwards Aquifer in the late 1980s provoked an enormous protest among Austin environmental activists. Dunn shows footage of Moffett claiming in a crowded all-night City Council hearing that "as a geologist, I know more about Barton Creek than anyone in this room" (June 7, 1990). One student even stated that Moffett's behavior "tends to offend rather than assure." Many commented on the relative credibility of the "environmentalists" in contrast to the developers, some of whom appeared "greedy."

Students noted not only pathos but ethos in Curtis Peterson. They admired the farmer's "strong" character, which derived its credibility from the way in which his life was affected by development. And finally, these students of science and technology found that the geologists who explained the workings of Barton Springs were the most credible speakers of all. This powerful appeal to scientific ethos also showed up in students' discussion of the film's logos.

\section{Logos}

Students noted fewer persuasive instances of logos than of pathos or ethos in the film, and we noticed fewer consistent patterns in their responses to questions about logos. Twenty-three students, however, listed the geologists' discussion of pollution, or the evidence of pollution given by geologists, as a persuasive example of logos. "I think this is effective," wrote one, "because I like scientific results and hard concrete facts."

The few students who disagreed did so not because of the geological evidence itself, but because of the filmic presentation. One argued that Dunn's dominant appeals to pathos and ethos "dampen[ed] the impact" of her appeals to logos. He cites one geologist who describes how pollution in the Edwards aquifer (Austin's water supply) occurs because the soil's natural filtration capacity is compromised by concrete. However, he wrote:

"The logical point is made very quickly and in conjunction with vivid urban scenes which ultimately distracts the viewer from [that] point. In fact, The Unforeseen typically overshadows the logical points with emotional appeals."

Another student critic argued:

"Instead of quoting actual statistics and providing concrete evidence, the 
filmmaker choose to artfully gloss over phrases from the aquifer report and newspaper headlines."

Five students valued the logical strength in Dunn's effort to balance her film with evidence "from both sides." One elaborated on how Dunn's method supported his reading of her claim:

"...by carefully intertwining and splicing segments from various players in the conflict, including testimony from people who stood to lose a lot regardless of the outcome ... she reinforced her claim that we can't have our cake and eat it too. One or another of the parties involved must be forced to accept less than they demand, and often a final resolution of a conflict comes about by everyone giving a little bit."

(student's emphasis; our ellipses)

Students were divided, however, in their assessment of the developers' logic in general. One, for instance, considered Kuykendall's argument for freeing developers from such constraints as regulated lot size to be logical, and well supported by Kuykendall's "economic example." Another protested that there was "no logic for this person besides his bank account."

Seen as a group, student responses to the film reinforced our earlier observations that identifying and evaluating logos is more difficult than pathos or ethos, and it requires more specific guidance and deliberate pedagogical strategies. From the students' self-identified examples of ethos and pathos, we identified fifteen and seventeen general categories, respectively. Patterns emerged in these responses, and usually more than one student would list a single example. On the other hand, fewer students volunteered examples on logos, there were thirty-three categories, and more singular responses. Many of these responses, moreover, showed limited understanding of logos and may have been simply a student's best guess.

\section{Analyzing Complexities}

Although students have some difficulty identifying examples of logos on their own in the written comments they make after initial viewing of The Unforeseen, in class discussion they are able to move toward a more complex analysis of the logic and evidence in the film. To stimulate that sort of analysis, we ask students to look at three different types of arguments -arguments of consequence, arguments of analogy, and arguments of principle. By examining the categories of arguments being used - definitional or evaluative -- students can get a better sense of the way arguments are put together and of the particular rhetorical strategies that are used to make appeals to logos in argumentation.

\section{Types of Arguments Presented in the Film}

Arguments using consequence or analogy fall into the category of definitional arguments and help establish the nature of the topic being debated. In the case of The Unforeseen, the film is asking "What is the impact (or consequence) of urban development?" and "What other things that we already understand does urban development resemble?" Students are able to identify several arguments in each category and engage in a spirited debate about the argument posed. 
For instance, one of the arguments in the film that elicits the most heated discussion is the section that compares an underwater scene of Barton Springs in 1996 against an underwater scene in 2004 (see Figs. 5 and 6). In the earlier scene, the water is clear and visibility is high; in the later scene, the water is cloudy and visibility is limited. Students recognize easily that this is an argument of consequence, which makes a cause and effect link between the cloudiness of the water and pollution from urban development. In order to analyze the argument, students must first identify the cause-effect link. Once that is established, they are better able to articulate their differences or agreements with the argument. Some students accept and agree with the argument that the cloudiness of the water is caused by pollution from development. In fact, some think that it is the most persuasive argument in the film. But many students question the evidence that links the effect to the cause. They want to know if the pool might not just be cloudier on a particular day, say after a rain. They are not persuaded by the evidence of two photographs and call into question the viability of using limited evidence in that way to make a point. That sort of critique, which is exactly the sort of analysis we want the film to stimulate, complicates the discussion and forces students to examine more sides of the issue.

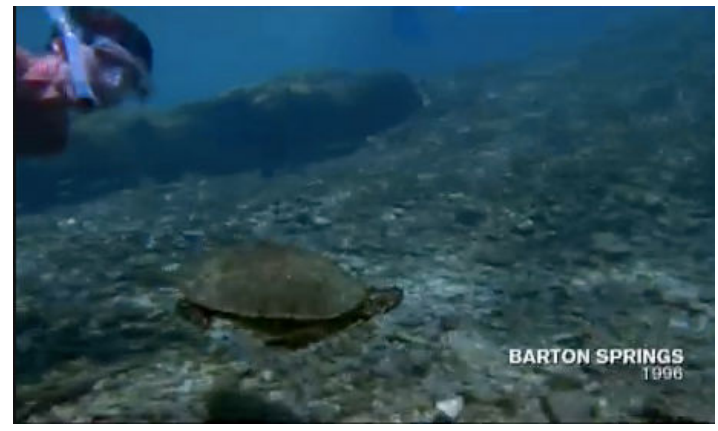

Figure 5. An underwater image of Barton Springs taken in 1996.

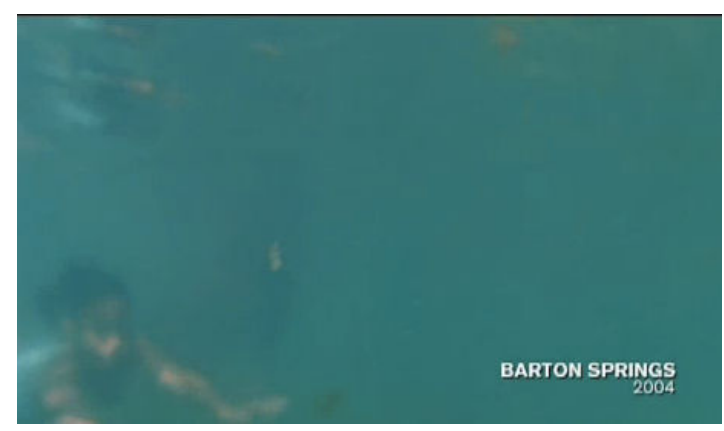

Figure 6. An underwater image of Barton Springs taken in 2004.

One argument of analogy in the film that stirs controversy in classroom discussion is the filmmaker's use of cancer as a metaphor for urban sprawl. This argument in particular gives us an opportunity to explore the way images are used to make an argument. Using an interview with oncologist Judah Folkman, the filmmaker establishes a definition of cancer as an unhealthy growth that threatens healthy growth and life itself. Through scenes that juxtapose images of cancer cells in the blood stream with images of urban construction tearing up the landscape, the film goes on to compare development to cancer. As students begin to identify the ways images in the film visually analogize the landscape to the human body, the highway system to the blood stream (see Figs. 7 and 8) and finally cancer to suburban sprawl, they begin to see the complexities of the argument more clearly. Students grapple in discussion with the legitimacy of the claim that suburban development is like sprawl. Some feel that it is unwarranted and exaggerated. Others feel that it is a valid argument. Usually some consensus is reached when students conclude that the film posits a distinct difference between healthy growth and unhealthy growth. 


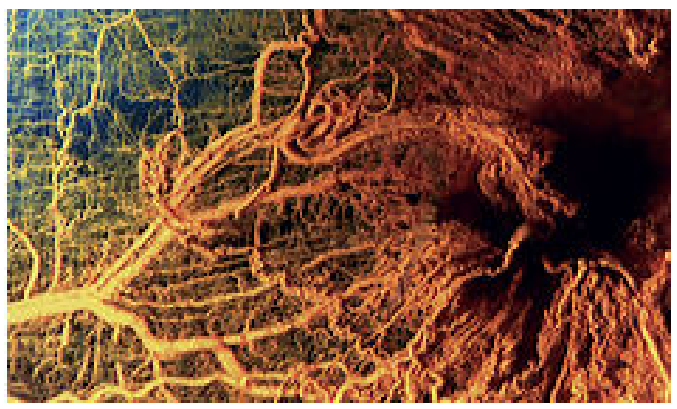

Figure 7. An image of veins and arteries in the human body.

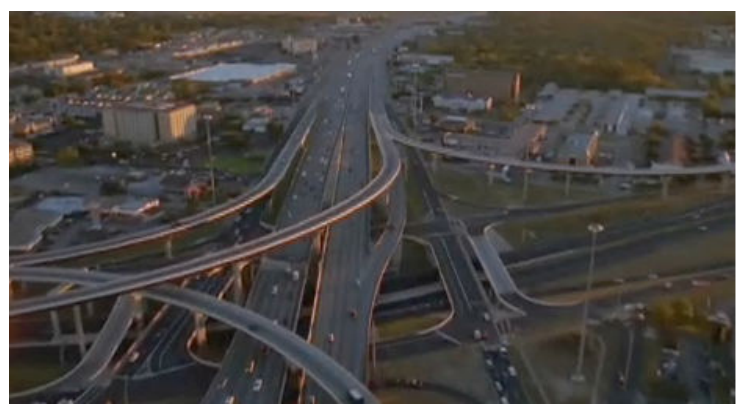

Figure 8. An image of freeways shown in juxtaposition to the bloodstream.

Arguments of principle, which move students into the realm of evaluative arguments, prove to be more difficult territory than the definitional arguments. And the film relies heavily on arguments of principle. For instance, one recurring theme in the film is that nature is sacred, created by a deity greater than us. That principle co-exists and sometimes collides with the American dream of homeownership. As the film shows, the American dream is complicated by the principles of private property rights, capitalism, and the free market. At some point those principles come into conflict with the principle of protecting the natural world (defined as sacred in the film). Those points of debate are sometimes difficult to navigate in the classroom. Some students object to the way certain principles, such as the principle of property rights, are called into question by the filmmaker, especially when emotional appeals are tied in with the arguments of principle. For instance, the filmmaker uses light, lyrical music to convey a sense of wonder when using images of the pristine natural world, and a heavy drumbeat to convey a sense of dread when showing images of construction and urban sprawl. Indeed, if we have one complaint about the pedagogical value of the film, it is that the semiotics of these dramatically contrasting musical accompaniments encourage duality of thinking in place of an awareness of the plurality of perspectives abounding. To the extent that students feel forced to choose between the American dream - represented by many figures, including a little boy playing outside his home in a new subdivision (see Figure 9) -- and an environmentalist view, they feel uncomfortable, and rightly so. But the point we want them to see is that all sides of the situation speak to principles most of us understand and many of us embrace. The film makes students aware that difficult conflicts the ones that are not about good against evil, but about good intentions against good intentions require thoughtful analysis if they are to be resolved.

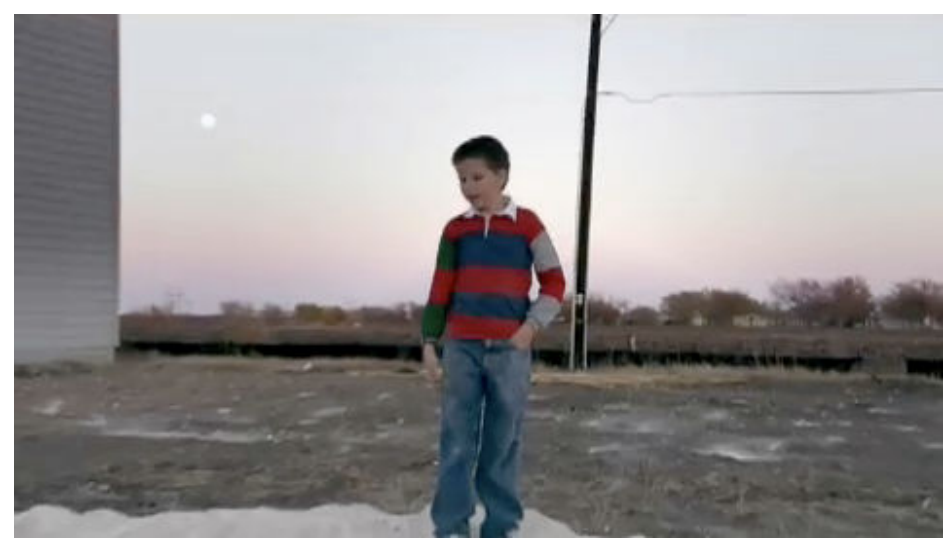


Figure 9. A boy playing outside his new home in a subdivision under development.

\section{How the Filmmaker Handles the Counterarguments}

One of the film's most useful pedagogical features is that, although the filmmaker never obscures her own position, she also never reduces the opposing argument to a straw man. As David Brancaccio notes in his PBS interview with Laura Dunn, "[ $t]$ he film is no polemic. It humanizes players on many sides of the environment versus the development clash." 1 None are humanized more that Gary Bradley, whose powerful appeal to pathos is noted in the discussion above. As Robert Koehler notes in his review of the film, "Dunn's thoughtfulness comes through most unexpectedly in the manner in which she interviews and captures the character of Gary Bradley, one of the area's most prominent developers." In Koehler's estimation Dunn refrains from pigeonholing Bradley "as the black hat of the piece." 5 Instead "Bradley embodies the hopes of a guy coming from a hardscrabble rural existence to realize his dreams as a land tycoon." Bradley is, in fact, portrayed so sympathetically in the film that Laura Dunn has been subject to much criticism from environmentalists in Central Texas. In a question and answer session after the film screened in Austin, she commented that she had "gotten more flack from the environmental community than from the developer community" ${ }^{7}$ because of her portrayal of Bradley. In response to that criticism, Dunn asserted her belief that "the ethics of documentary filmmaking" requires her to respect her subjects and be "considerate to [developers] and [environmentalists] and everyone in between." She also accepted the criticism as sign of the film's success since she believes in "the power of art to subvert people's expectations and to disorient them and see the world a little differently." 7

\section{Conclusions}

In general our students resist arguments that feel like indoctrination. Although students recognize Dunn's position in The Unforeseen, her attempt to portray fairly all sides of the argument pays off for us, as teachers, in several ways. The fact that Dunn approaches the controversy respectfully sets the stage for respectful disagreements in class discussion. In addition, because our students do not dismiss The Unforeseen as a one-sided polemic, they seem to engage in a deeper, more thorough analysis than we have seen them perform with other documentaries. Even when they critique what they see as bias in the film, they have to work to figure out what Dunn is saying. There are no easy answers. Students must listen to the music, deconstruct metaphors, figure out what the filmmaker is trying to say about Gary Bradley and developers in general and what she is saying about the American dream. In short, because the filmmaker herself does not reduce the difficulties of the issue, she models for the students a reality of critical thinking: that the world is not black and white, that there are many dimensions to every controversy.

For example, one unusually self-aware student performed a meta-analysis that tracked his own responses to highlight Dunn's method:

"Over $90 \%$ of the movie is simply watching video and letting your mind think about what you are seeing. Often, when someone is talking to you, it shows the person talking. That way, you are fully focused on what that person has to say. 
When he is done talking, the film shows a clip that pertains to what was just said. Then it gives you time to think about what you just heard and what you are seeing and make your own conclusions. Then it gives you Dunn's conclusions, along with the conclusions of the other interested parties...Using three different points of view, four if you include the viewer, Dunn shines light on every angle of the situation."

This detailed and perceptive comment suggests that our students have the potential not only to analyze arguments and identify their responses, but to use those responses to analyze the presentation more fully and deeply.

This capacity is important for this next generation of engineers who will need to engage with increasingly sophisticated and manipulative media related to such fields as energy conservation, pollution control, sustainability, and infrastructure. Equipped with an appreciation of the plurality of perspectives surrounding most engineering and social issues, and a capacity to fairly and ethically argue rather than overbear, our students may set new standards for full and informed social debates in the lab, the boardroom, or all-night City Council meetings. Our conclusion is that lessons learned through analysis of a film like The Unforeseen help students to develop their analytical skills and in the process become better thinkers, better engineers, and better citizens.

\section{References}

1. NOW. (June 15, 2007) Transcript: The Unforeseen. David Brancaccio interview of Laura Dunn. Retrieved on January 26, 2009 from (http://www.pbs.org/now/shows/324/transcript.html).

2. Shuman, Larry, et. al. (2002). The Future of Engineering Education. 32 ${ }^{\text {nd }}$ ASEE/IEEE Frontiers in Education Annual Conference. Boston, MA: IEEE.

3. Bean, John and Ramage, John. (1992) Writing Arguments: A Rhetoric with Readings. $2^{\text {nd }}$, edition. New York, NY: MacMillan.

4. Smith, Gavin. (March/April 2007) Film Comment. FESTIVALS/SUNDANCE: The Sad Eyes of Park City. Retrieved on February 5 at http://www.filmlinc.com/fcm/ma07/sundance2.htm.

5. Koehler, Robert. (January 20, 2007). Variety. The Unforseseen. Retrieved on February 5, 2009 from http://www.variety.com/index.asp?layout=festivals\&jump=review\&id=2471\&reviewid=VE1117932630\&cs=1.

6. The Unforeseen. (2008) Official Website. Terrence Malick and Robert Redford producers. Retrieved on February 5, 2009 from http://www.twobirdsfilm.com/home.htm).

7. Hartman, Russ. July 3, 2008. Laura Dunn and Robert Redford - The Unforeseen. Excerpt from Q \&A held at the Alamo Draft House. AustinDaze. Retrieved on January 22, 2009 from http://www.austindaze.com/2008/07/03/laura-dunn-and-robert-redford/. 


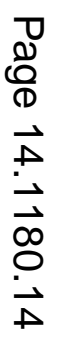

